\title{
Knowledge, Attitudes and Practices about Parentally Transmitted Hepatitis among Barbers and their Customers in Assiut District
}

\author{
Shimaa A.K. Ahmed, Madiha M. H. El-Attar, Safaa A. M. Kotb, Mohamed Z. Abdel-Rhman, \\ Department of Community Health Nursing, Faculty of Nursing, Assiut University, \\ Department of Tropical Medicine and Gastroenterology, Faculty of Medicine, Assiut University, \\ Department of Clinical Pathology, Faculty of Medicine, Assiut University
}

\begin{abstract}
Hepatitis $\mathrm{C}$ virus (HCV) is an emerging global epidemic disease. Egypt reported the highest incidence in the world. Aim of the study: To assess knowledge, attitudes and practices of barbers and their customers regarding HCV and HBV. Setting: The study carried out in Assiut District and City. Design: Descriptive research design. Sample: Included 350 participants (175 barbers and 175 customers). Tools of the study: Data collected by three tools; Tool (1): interview form included three parts; first part included demographic data; second part included assessment of medical and surgical history of barbers and customers and third part included assessment of knowledge regarding the HCV\&HBV. Tool (2): Included Likert attitude scale. Tool (3): Observational checklist to assess practices of barbers and customers. Results: Majority of barbers and their customers (88.6\% and $80.6 \%$ respectively) had poor knowledge regarding HCV and HBV. Conclusion: There was a statistical significant difference among customers' knowledge, their level of education and their residence. Moreover there was a significant difference between customers' attitude and their residence. Recommendations: Need for ongoing training and retraining programs for barbers regarding methods of prevention of parentally transmitted hepatitis. Increase public awareness about risk factors and prevention methods of HCV and HBV infection.
\end{abstract}

Key Words: HCV\&HBV, Barbers, Knowledge \& Practices.

\section{Introduction}

Hepatitis is an inflammation of the liver, most commonly caused by a viral infection. There are five main hepatitis viruses, referred to as types A, B, C, D and E. Hepatitis B virus (HBV) and Hepatitis $C$ virus (HCV) are the main causes of severe liver disease as Hepato Cellular Carcinoma (HCC). WHO, (2012) estimated that over 2 billion people have been infected with HBV and 170 million HCV infected patients world-wide. HBV is 50 to 100 times more infectious than Human Immunodeficiency Virus (HIV) (Jokhio et al., 2007, Averhoff, 2012 and World Health Organization (WHO), 2012 ).

Recent studies carried out in Egypt showed that the prevalence rates of $\mathrm{HBV}$ have been decreased (Ismail et al, 2009 and Hwang and Cheung, 2011). The prevalence of HCV antibodies (anti- HCV) is reported to be higher in Egypt than in any other country, where the prevalence of infection increases steadily with age. This difference has been attributed to past infection and treatment of schistosomiasis (Medhat et al, 2002 and Shalaby et al., 2007).

There is strong evidence that razors, barber's scissors, nail files and body piercing instruments are risk factors for transmission of $\mathrm{HCV}$ and $\mathrm{HBV}$. Barbers are a significant proportion of population who may expose to $\mathrm{HBV}$ and/or $\mathrm{HCV}$ and become chronically infected. These infected people may not be aware of their HBV and/or HCV status and they are not clinically ill but they act as a source of infection to others (Jokhio et al, 2007, Wazir et al, 2008 and Amodio et al, 2009).

Nurses and other primary health care providers play an important role in dealing with pre-and post-test discussions as part of diagnostic testing for HCV and HBV. Nurses specializing in liver conditions can impact public health through innovative educational programs. Provision of thorough test discussion in a primary health care setting utilizes a valuable educational opportunity to help minimize $\mathrm{HCV}$ and HBV transmission in the community (Poll, 2009).

\section{Significance of the study}

Egypt has the largest HCV prevalence in the world with $(14.7 \%)$ of the population being antibody positive for $\mathrm{HCV}$. HBV is 50 to 100 times more infectious than HIV. Barbers and their customers as risk group for acquiring $\mathrm{HCV}$ and $\mathrm{HBV}$, should be provided with high awareness about $\mathrm{HCV}$ and $\mathrm{HBV}$ to avoid the risk of infectious agents transmission by reusing of razors and scissors on multiple clients (Jokhio et al., 2007 and Mohamoud et al., 2012). HCV and HBV transmission through sharing of nonsterile sharp instruments such as those used for barbering have always been given less attention in the 
campaign against the spread of $\mathrm{HCV}$ and $\mathrm{HBV}$ (Eassa et al, 2007).

\section{Aim of the study}

To assess knowledge, attitudes and practices of barbers and their customers regarding $\mathrm{HCV}$ and HBV.

\section{Subjects and Methods}

\section{Study design}

Descriptive research design was used in this study.

\section{Study setting}

The current study carried out at Assiut Distract and City: Assiut Distract: It is composing from 7 rural local units (which include 25 villages); total coverage for all these villages were carried out due to small number of barbers' shops and to represent the rural localities in the current study. Assiut City: Data collected according to administrative classification into (East and West sector) to represent the urban localities in the current study.

\section{Sample characteristics}

The target population involved people working in barbers' shops and practicing hair-cutting and shaving at a rotating daily open shops and one attending customer from each shop.

\section{Sample selection technique}

Sample size calculated by using EPI/Info 2000, version (3.3), with power $80 \%$ and CI 95\%; on the lowest prevalence of the disease $(10 \%)$. The sample size that could detect the prevalence rate of the disease using was estimated to be 280 persons. To avoid drop out and refusal; sample size was increased to be 350 subjects (175 barbers and 175 customers). Randomly selected barbers' shops were done to represent the different socioeconomic standards.

Tools of the study: Three tools were used in data collection

An interview form composed from three tools was used in the current study; First tool: Included three parts

Part (1): Demographic characteristics of the participated barbers and their customers

It included demographic characteristics such as: Name, educational level...etc. More over, there were (4 questions) were asked for barbers only such as: Years of experience in barbing, working in another job rather than barbing...etc.

Part (2): Previous risky behaviors of the participated barbers and their customers

This part used to assess the previous risky behaviors of the participated barbers and their customers such as: Visiting dentist, having tattoo .....etc.
Part (3): Knowledge of barbers and their customers about $\mathrm{HCV}$ and $\mathrm{HBV}$

This part used to assess knowledge of the studied sample Total score of knowledge were (40). Using score system for knowledge, a correct response was scored (1) grade and zero for the incorrect (poor= score $<50 \%$, satisfactory $=$ score $50-70 \%$ and good $=$ score $>70 \%$ ) (Al-Thaqafy et al, 2009).

Second tool (Likert scale): Assessment of barbers and their customers' attitudes three points Likert scale: agree, uncertain and disagree. These were scored (2, 1 and 0$)$ respectively. The scoring was reversed for negative statements. A total score was calculated by summing up and converted into a percent score. Attitude was considered positive if the score was $>70 \%$ and negative attitude if the score < $70 \%$.

\section{Validity of Likert scale items}

This scale was reviewed by (7 experts), from medical and nursing staff in Assiut University to assess and evaluate the scale items to secure the validity of this tool. Modifications were done according to the directions of the experts committee.

Third tool: It included an observational checklist, used to record the observed practices of barbers and their customers to assess their risky behaviors during shaving and hair-cutting practice.

\section{Study phases}

\section{I- Administrative phase}

An official letters of approval was obtained from the Dean of the Faculty of Nursing, Assiut University was sent to Assiut Governor for permission to carry out the study in the selected areas.

\section{II- Pilot study}

Pilot study was carried out before starting the data collection phase on 10 persons ( 5 barbers and 5 customers). The aim of this phase was to test the clarity of the tools and to estimate the required time to fill the study tools.

\section{III- Ethical considerations}

The study approved by Faculty of Nursing, Assiut University ethical review committee. The people were recruited to the study informed about the objectives of the study and that they are free to refuse participation. A verbal witnessed consent obtained from the participants. The confidentiality of the collected data was assured.

\section{IV- Data collection phase}

\section{Field work}

Data was collected for around eighteen months from (9/5/2012 to $27 / 11 / 2013)$. Before visiting the barbers' shops in the selected settings, there were a preparation phases for the visit were arranged with the community leaders (well-known persons in every 
village) and one of the inhabitants in Assiut City. The average length of each interview was (30-40) minutes. Every week about (15-20) sheets were finished. Data was collected (three days/ week).

\section{Results}

Table (1): Demographic characteristics of barbers and their customers in Assiut District, 2012/2013

\begin{tabular}{|c|c|c|c|c|}
\hline \multirow{2}{*}{ Demographic characteristics } & \multicolumn{2}{|c|}{ Barbers $(n=175)$} & \multicolumn{2}{|c|}{ Customers $(n=175)$} \\
\hline & No. & $\%$ & No. & $\%$ \\
\hline \multicolumn{5}{|l|}{ Age (years) } \\
\hline$<25$ years & 42 & 24.0 & 34 & 19.4 \\
\hline $25-<30$ years & 58 & 33.1 & 47 & 26.8 \\
\hline $30-<35$ years & 22 & 12.6 & 29 & 16.6 \\
\hline $35-<40$ years & 18 & 10.3 & 22 & 12.6 \\
\hline$\geq 40$ years & 35 & 20.0 & 43 & 24.6 \\
\hline Mean \pm SD (Range) & \multicolumn{2}{|c|}{$31.72 \pm 11.20(17-65)$} & \multicolumn{2}{|c|}{$32.57 \pm 9.47(17-60)$} \\
\hline \multicolumn{5}{|l|}{ Educational level } \\
\hline Illiterate & 50 & 28.6 & 25 & 14.3 \\
\hline $\begin{array}{l}\text { Primary } \\
\end{array}$ & 11 & 6.3 & 12 & 6.9 \\
\hline Preparatory & 14 & 8.0 & 10 & 5.7 \\
\hline Secondary & 94 & 53.7 & 102 & 58.3 \\
\hline University & 6 & 3.4 & 26 & 14.8 \\
\hline \multicolumn{5}{|l|}{ Marital status } \\
\hline Single & 69 & 39.4 & 61 & 34.9 \\
\hline Married & 106 & 60.6 & 114 & 65.1 \\
\hline \multicolumn{5}{|l|}{ Residence: } \\
\hline Rural & 58 & 33.1 & 61 & 34.9 \\
\hline Urban & 117 & 66.9 & 114 & 65.1 \\
\hline
\end{tabular}

Fig (1): Total score of knowledge for barbers regarding HCV and HBV in Assiut District, 2012/2013

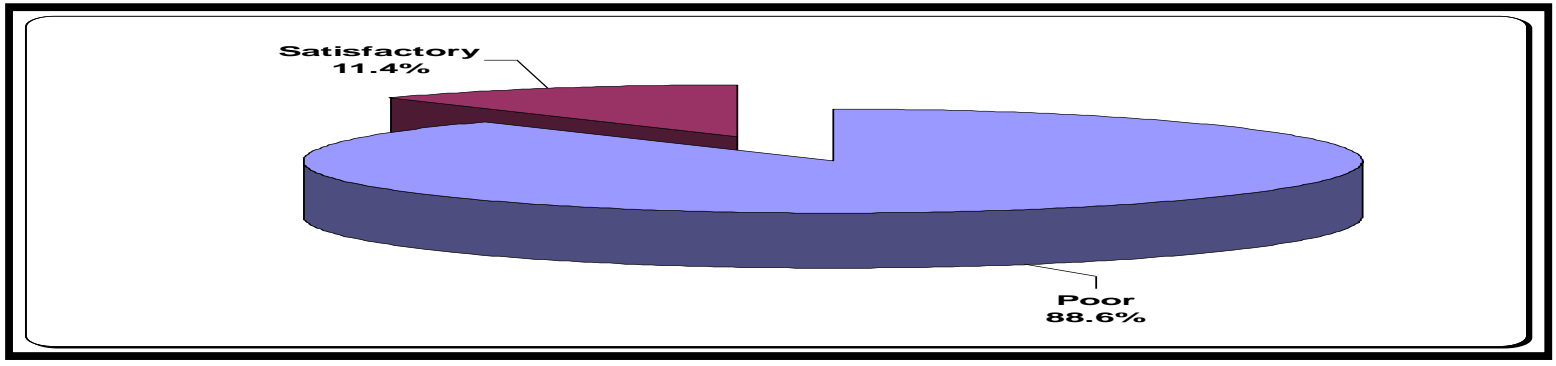

Fig (2): Total score of knowledge for customers regarding HCV and HBV in Assiut District, 2012/2013

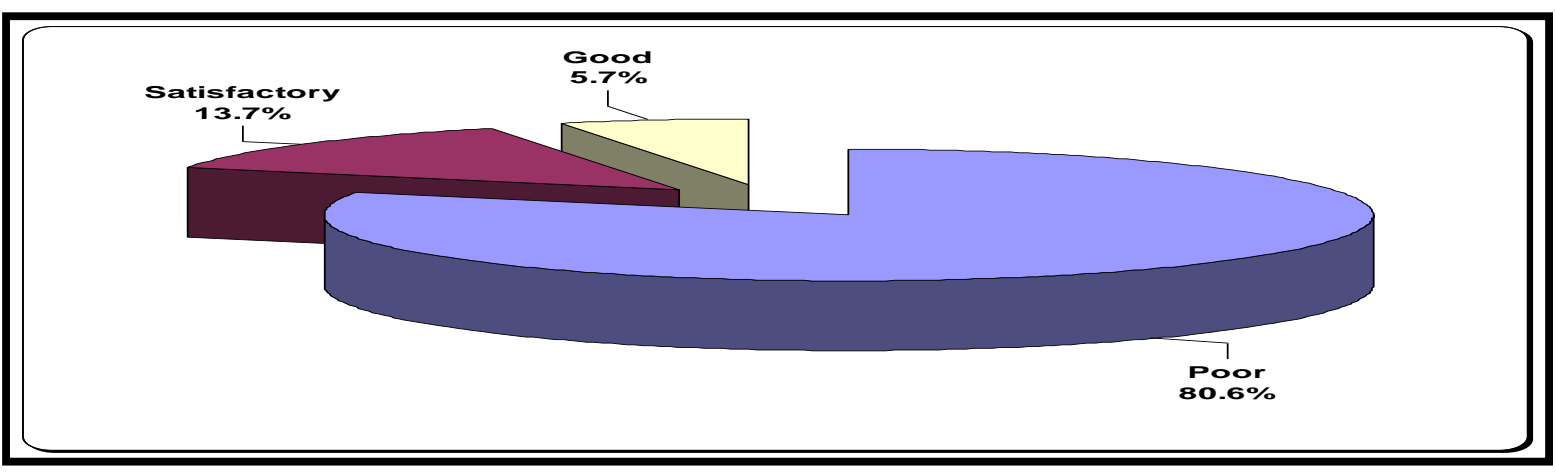


Fig (3): Knowledge of barbers about the shaving tools that may transmit HCV and HBV in Assiut District, 2012/2 013

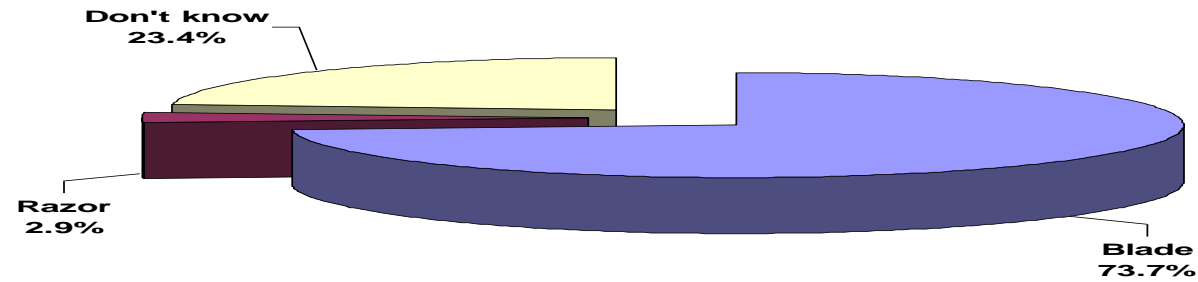

Fig (4): Attitudes of barbers regarding HCV and HBV in Assiut District, 2012/2013

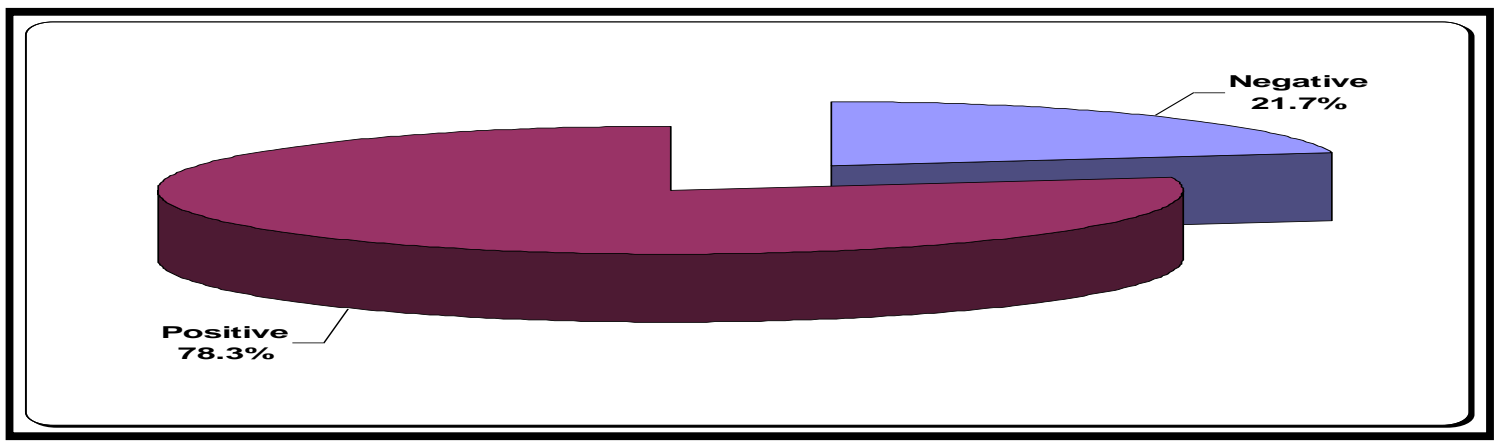

Fig (5): Attitudes of customers regarding HCV and HBV in Assiut District, 2012/2013

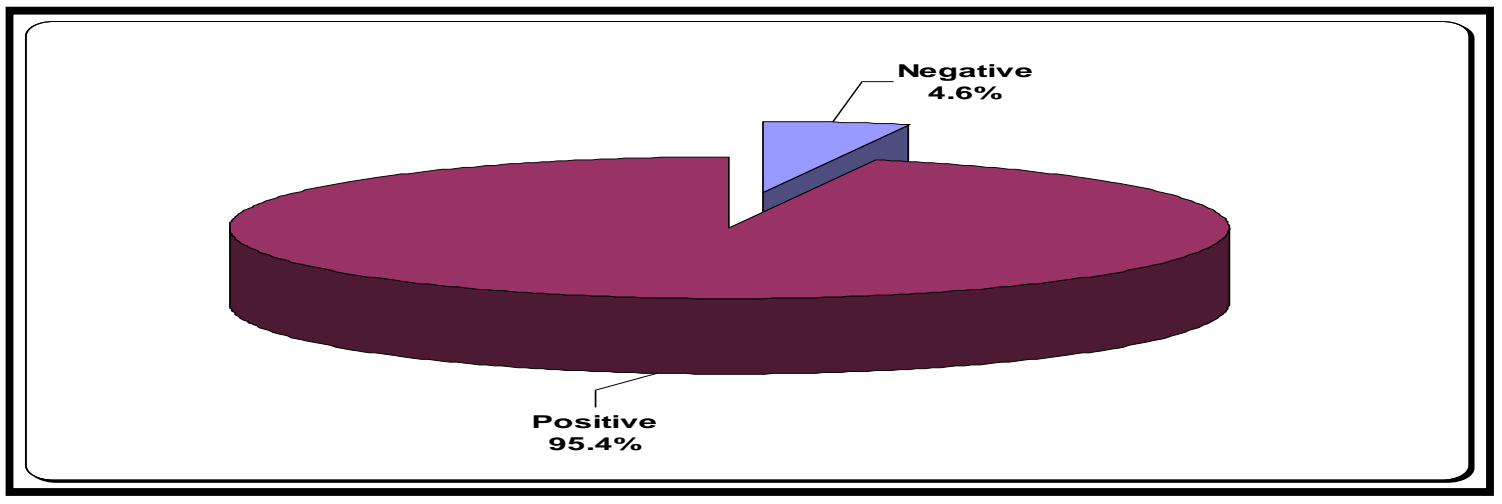

Table (2): Observed risky practices of barbers during shaving by residence in Assiut District, 2012/2013

\begin{tabular}{|c|c|c|c|c|c|}
\hline \multirow[b]{2}{*}{ Items } & \multicolumn{2}{|c|}{ Rural $(n=58)$} & \multicolumn{2}{|c|}{ Urban $(n=117)$} & \multirow[b]{2}{*}{ P-value } \\
\hline & No. & $\%$ & No. & $\%$ & \\
\hline Washes hands between each customer & 2 & 3.4 & 0 & 0.0 & 0.206 \\
\hline Changes the towels between each customer & 1 & 1.7 & 8 & 6.8 & 0.281 \\
\hline Presence of plastic gloves and use it for every customer & 1 & 1.7 & 0 & 0.0 & 0.719 \\
\hline Uses the electric shaver & 56 & 96.5 & 115 & 98.3 & 0.851 \\
\hline Uses a new razor for each client & 56 & 96.5 & 114 & 97.4 & 0.741 \\
\hline Sets a new apron for each customer & 1 & 1.7 & 0 & 0.0 & 0.719 \\
\hline Uses a new blade on each new customer & 1 & 1.7 & 10 & 8.5 & 0.156 \\
\hline
\end{tabular}




\begin{tabular}{|c|c|c|c|c|c|}
\hline \multirow[b]{2}{*}{ Items } & \multicolumn{2}{|c|}{ Rural $(n=58)$} & \multicolumn{2}{|c|}{ Urban $(n=117)$} & \multirow[b]{2}{*}{ P-value } \\
\hline & No. & $\%$ & No. & $\%$ & \\
\hline Using of potash aluminum (Shaba) & 1 & 1.7 & 0 & 0.0 & 0.719 \\
\hline Gets rid of razors in the waste products basket & 5 & 8.6 & 35 & 29.9 & $0.002 *$ \\
\hline Changing of the disinfectant liquid frequently & 1 & 1.7 & 3 & 2.6 & 0.726 \\
\hline Sweeps the shop floor after every customer & 5 & 8.6 & 25 & 21.4 & $0.035^{*}$ \\
\hline Using Dettol as anti septic solution & 5 & 8.6 & 9 & 7.7 & 0.831 \\
\hline Using Alcohol as anti septic solution & 28 & 48.3 & 85 & 72.6 & $0.002 *$ \\
\hline Using Colonia as anti septic solution & 25 & 43.1 & 23 & 19.7 & $0.001 *$ \\
\hline
\end{tabular}

${ }^{(*)}$ There was a significant difference Chi square test

Significant at $P<0.05$

Table (3): Shaving practices of customers in Assiut District, 2012/2013

\begin{tabular}{|l|c|c|}
\hline \multicolumn{1}{|c|}{ Variables } & No. (n= 175) & \% \\
\hline Shaving at only one barber's shop & 153 & 87.4 \\
\hline From how long & & \\
\hline$<5$ years & 49 & 32.0 \\
\hline $5-<10$ years & 34 & 22.2 \\
\hline $10-<15$ years & 36 & 23.5 \\
\hline$\geq 15$ years & 34 & 22.2 \\
\hline Times of shaving/ month & 29 & 16.6 \\
\hline One & 51 & 29.1 \\
\hline Two & 28 & 16.0 \\
\hline Three & 64 & 36.6 \\
\hline Four & 3 & 1.7 \\
\hline Five & 76 & 43.4 \\
\hline Can shave at home & 76 & 43.4 \\
\hline Owning shaving equipments at home & 24 & 31.6 \\
\hline Sharing personal equipments with family members at home & 7 & 4.0 \\
\hline Asking barber to wish his hands before shaving & 9 & 5.1 \\
\hline Verifying the sterilization of shaving equipments & 3 & 1.7 \\
\hline Bringing their own equipments & \\
\hline
\end{tabular}

Table (4): Scores of knowledge and demographic characteristics of barbers and about HCV and HBV in Assiut District, 2012/2013

\begin{tabular}{|c|c|c|c|c|c|}
\hline \multirow{3}{*}{ Demographic characteristics } & \multicolumn{4}{|c|}{ Score of knowledge $(n=175)$} & \multirow{3}{*}{ P-value } \\
\hline & \multicolumn{2}{|c|}{ Poor $(n=155)$} & \multicolumn{2}{|c|}{ Satisfactory $(n=20)$} & \\
\hline & No. & $\%$ & No. & $\%$ & \\
\hline \multicolumn{5}{|l|}{ Age: (years) } & \multirow{6}{*}{0.836} \\
\hline$<25$ & 38 & 90.5 & 4 & 9.5 & \\
\hline $25-<30$ & 51 & 87.9 & 7 & 12.1 & \\
\hline $30-<35$ & 18 & 81.8 & 4 & 18.2 & \\
\hline $35-<40$ & 16 & 88.9 & 2 & 11.1 & \\
\hline$\geq 40$ years & 32 & 91.4 & 3 & 8.6 & \\
\hline \multicolumn{5}{|l|}{ Level of education } & \multirow{4}{*}{$0.000 *$} \\
\hline Illiterate & 50 & 100.0 & 0 & 0.0 & \\
\hline Basic education & 25 & 100.0 & 0 & 0.0 & \\
\hline Secondary/ higher & 80 & 80.0 & 20 & 20.0 & \\
\hline \multicolumn{5}{|l|}{ Residence } & \multirow{3}{*}{0.411} \\
\hline Rural & 53 & 91.4 & 5 & 8.6 & \\
\hline Urban & 102 & 87.2 & 15 & 12.8 & \\
\hline
\end{tabular}




\begin{tabular}{|c|c|c|c|c|c|}
\hline \multirow{3}{*}{ Demographic characteristics } & \multicolumn{4}{|c|}{ Score of knowledge $(n=175)$} & \multirow{3}{*}{ P-value } \\
\hline & \multicolumn{2}{|c|}{ Poor $(n=155)$} & \multicolumn{2}{|c|}{ Satisfactory $(n=20)$} & \\
\hline & No. & $\%$ & No. & $\%$ & \\
\hline \multicolumn{5}{|l|}{ Marital status } & \multirow{3}{*}{0.588} \\
\hline Single & 60 & 87.0 & 9 & 13.0 & \\
\hline Married & 95 & 89.6 & 11 & 10.4 & \\
\hline \multicolumn{5}{|l|}{ Working experience } & \multirow{4}{*}{0.378} \\
\hline$<10$ years & 49 & 90.7 & 5 & 9.3 & \\
\hline $10-<20$ years & 68 & 85.0 & 12 & 15.0 & \\
\hline$\geq 20$ years & 38 & 92.7 & 3 & 7.3 & \\
\hline
\end{tabular}

Table (5): Scores of knowledge and demographic characteristics of customers about HCV and HBV in Assiut District, 2012/2013

\begin{tabular}{|c|c|c|c|c|c|}
\hline \multirow{3}{*}{ Demographic characteristics } & \multicolumn{4}{|c|}{ Score of knowledge (No. 175) } & \multirow{3}{*}{ P-value } \\
\hline & \multicolumn{2}{|c|}{ Poor $(n=141)$} & \multicolumn{2}{|c|}{ Satisfactory $(n=34)$} & \\
\hline & No. & $\%$ & No. & $\%$ & \\
\hline \multicolumn{5}{|l|}{ Age (years) } & \multirow{6}{*}{0.576} \\
\hline$<25$ & 30 & 88.2 & 4 & 11.8 & \\
\hline $25-<30$ & 36 & 76.6 & 11 & 23.4 & \\
\hline $30-<35$ & 25 & 86.2 & 4 & 13.8 & \\
\hline $35-<40$ & 17 & 77.3 & 5 & 22.7 & \\
\hline$\geq 40$ & 33 & 76.7 & 10 & 23.3 & \\
\hline \multicolumn{5}{|l|}{ Level of education } & \multirow{4}{*}{$0.007 *$} \\
\hline Illiterate & 23 & 92.0 & 2 & 8.0 & \\
\hline Basic education & 22 & 100.0 & 0 & 0.0 & \\
\hline Secondary/higher & 96 & 75.0 & 32 & 25.0 & \\
\hline \multicolumn{5}{|l|}{ Residence } & \multirow{3}{*}{$0.039 *$} \\
\hline Rural & 44 & 72.1 & 17 & 27.9 & \\
\hline Urban & 97 & 58.1 & 17 & 14.9 & \\
\hline \multicolumn{5}{|l|}{ Marital status } & \multirow{3}{*}{0.458} \\
\hline Single & 51 & 83.6 & 10 & 16.4 & \\
\hline Married & 90 & 78.9 & 24 & 21.1 & \\
\hline
\end{tabular}

${ }^{(*)}$ There was a significant difference

Chi square test

Significant at $P<0.05$

Table (6): Attitude and demographic characteristics of barbers toward HCV and HBV in Assiut District, 2012/2013

\begin{tabular}{|c|c|c|c|c|c|}
\hline \multirow{3}{*}{ Demographic characteristics } & \multicolumn{4}{|c|}{ Likert scale for attitude $(n=175)$} & \multirow{3}{*}{ P-value } \\
\hline & \multicolumn{2}{|c|}{ Negative $(n=38)$} & \multicolumn{2}{|c|}{ Positive $(n=137)$} & \\
\hline & No. & $\%$ & No. & $\%$ & \\
\hline \multicolumn{5}{|l|}{ Level of education } & \multirow{4}{*}{0.065} \\
\hline Illiterate & 13 & 26.0 & 37 & 74.0 & \\
\hline Basic education & 9 & 36.0 & 16 & 64.0 & \\
\hline Secondary or higher & 16 & 16.0 & 84 & 84.0 & \\
\hline \multicolumn{5}{|l|}{ Working experience } & \multirow{4}{*}{0.201} \\
\hline$<10$ years & 8 & 14.8 & 46 & 85.2 & \\
\hline $10-<20$ years & 22 & 27.5 & 58 & 72.5 & \\
\hline$\geq 20$ years & 8 & 19.5 & 33 & 80.5 & \\
\hline \multicolumn{5}{|l|}{ Residence } & \multirow{3}{*}{$0.035^{*}$} \\
\hline Rural & 18 & 31.0 & 40 & 69.0 & \\
\hline Urban & 20 & 17.1 & 97 & 82.9 & \\
\hline
\end{tabular}

${ }^{(*)}$ There was a significant difference 
Table (7): Risk factors for acquiring HCV and HBV among barbers and their customers in Assiut District, $2012 / 2013$.

\begin{tabular}{|c|c|c|c|c|c|c|c|c|c|c|}
\hline \multirow{3}{*}{ Risk factors } & \multicolumn{4}{|c|}{ Barbers (n=175) } & \multirow{3}{*}{ P-value } & \multicolumn{4}{|c|}{ Customers $(n=175)$} & \multirow{3}{*}{ P-value } \\
\hline & \multicolumn{2}{|c|}{$\begin{array}{c}\text { Rural } \\
(n=58)\end{array}$} & \multicolumn{2}{|c|}{$\begin{array}{c}\text { Urban } \\
(\mathbf{n}=117)\end{array}$} & & \multicolumn{2}{|c|}{$\begin{array}{c}\text { Rural } \\
(n=61)\end{array}$} & \multicolumn{2}{|c|}{$\begin{array}{c}\text { Urban } \\
(n=114)\end{array}$} & \\
\hline & No. & $\%$ & No. & $\%$ & & No. & $\%$ & No. & $\%$ & \\
\hline \multicolumn{5}{|c|}{ Goza (shesha) smoking in group } & \multirow{3}{*}{0.704} & & & & & \multirow{3}{*}{$0.022 *$} \\
\hline Yes & 20 & 34.5 & 37 & 31.6 & & 20 & 32.8 & 20 & 17.5 & \\
\hline No & 38 & 65.5 & 80 & 68.4 & & 41 & 67.2 & 94 & 82.5 & \\
\hline \multicolumn{5}{|c|}{ Having tattoo in the body } & \multirow{3}{*}{1.000} & & & & & \multirow{3}{*}{ - } \\
\hline Yes & 0 & 0 & 1 & 0.8 & & 0 & 0 & 0 & 0 & \\
\hline No & 58 & 100.0 & 116 & 99.2 & & 61 & 100.0 & 114 & 100.0 & \\
\hline \multicolumn{5}{|l|}{ Visiting a dentist } & \multirow{3}{*}{0.532} & & & & & \multirow{3}{*}{0.291} \\
\hline Yes & 6 & 10.3 & 16 & 13.7 & & 2 & 3.3 & 10 & 8.8 & \\
\hline No & 52 & 89.6 & 101 & 86.3 & & 59 & 96.7 & 104 & 91.2 & \\
\hline \multicolumn{5}{|c|}{ Blood exposure during barbing practice } & \multirow{3}{*}{$0.010^{*}$} & & & & & \multirow{3}{*}{ - } \\
\hline Yes & 42 & 72.4 & 61 & 52.1 & & - & - & - & - & \\
\hline No & 16 & 27.6 & 56 & 47.9 & & - & - & - & - & \\
\hline \multicolumn{5}{|c|}{ Taking intravenous treatment } & \multirow{3}{*}{0.806} & & & & & \multirow{3}{*}{0.606} \\
\hline Yes & 0 & 0 & 2 & 1.7 & & 1 & 1.6 & 5 & 4.4 & \\
\hline No & 58 & 100.0 & 115 & 98.3 & & 60 & 98.4 & 109 & 95.6 & \\
\hline \multicolumn{5}{|c|}{ Conduction of surgical operation } & \multirow{3}{*}{0.549} & & & & & \multirow{3}{*}{0.420} \\
\hline Yes & 11 & 19.0 & 18 & 15.4 & & 12 & 19.7 & 17 & 14.9 & \\
\hline No & 47 & 81.0 & 99 & 84.6 & & 49 & 80.3 & 97 & 85.0 & \\
\hline \multicolumn{5}{|l|}{ Type of surgery } & \multirow{3}{*}{0.688} & & & & & \\
\hline Major operation & 1 & 9.0 & 4 & 22.2 & & 8 & 66.7 & 9 & 52.9 & 0.722 \\
\hline Minor operation & 10 & 90.9 & 14 & 77.8 & & 4 & 33.3 & 8 & 47.1 & \\
\hline Endoscopic procedur & & & & & & & & & & \\
\hline Yes & 0 & 0 & 0 & 0 & - & 0 & 0 & 3 & 2.6 & 0.505 \\
\hline No & 58 & 100.0 & 117 & 100.0 & & 61 & 100.0 & 111 & 97.4 & \\
\hline Schistosomal treatme & & & & & & & & & & \\
\hline Yes & 6 & 10.3 & 0 & 0 & $0.002 *$ & 0 & 0 & 7 & 6.1 & 0.116 \\
\hline No & 52 & 89.6 & 117 & 100.0 & & 61 & 100.0 & 107 & 93.9 & \\
\hline
\end{tabular}

${ }^{(*)}$ There was a significant difference

Table (1): Illustrates that one-third of barbers and more than one-quarter of customers $(33.1 \%$ and $26.8 \%$ respectively) were in the age group from 25 $<30$ years. Regarding to the educational level, it was observed that $(28.6 \%)$ from the studied barbers were illiterate compared by $(14.3 \%)$ of the studied customers. While, there were $(53.7 \%$ and $58.3 \%$ respectively) from barbers and customers had secondary education. Concerning marital status, it was noticed that $(60.6 \%$ and $65.1 \%$ respectively) from them were married.

Fig (1): This figure shows that the majority of barbers $(88.6 \%)$ had poor score of knowledge about HCV \& HBV. While, only (11.4\%) of them had satisfactory score of knowledge regarding $\mathrm{HCV} \&$ HBV.

Fig (2): This figure shows that the majority of customers $(80.6 \%)$ had poor score of knowledge.
While only $(5.7 \%)$ of them had good score of knowledge about HCV and HBV.

Fig (3): This figure shows that $(73.7 \%)$ of the studied barbers mentioned that blade is the most used shaving tools that may transmit infection with $\mathrm{HCV}$ and HBV.

Fig (4): This figure presents that more than threequarters $(78.3 \%)$ of barbers had positive attitude toward $\mathrm{HCV}$ and $\mathrm{HBV}$.

Fig (5): This figure reveals that the vast majority of customers $(95.4 \%)$ had positive attitude toward HCV and HBV.

Table (2): Regarding to the observed practice of hand washing, only $(3.4 \%)$ of the rural barbers washed their hands between each customer compared with no one from urban barbers. Moreover $(1.7 \%)$ of rural barbers changed the towels between each customer. Also, more than one-fifth of urban barbers (21.4\%) were sweeping the shop floor after every customer with statistical difference $(\mathrm{P}=0.035)$. As well as, there 
were statistical differences between practices of rural and urban barbers regarding to (get rid of razors, using alcohol and Colonia as anti septic solution), were $(\mathrm{P}=0.002,0.002$ and 0.001 respectively).

Table (3): Illustrates that the majority of customers $(87.4 \%)$ were shaving at one barber's shop. While, it was observed that more than two-fifths of them $(43.4 \%)$ reported that they can shave at their home with their personal shaving equipments. In addition, it was noticed that the vast-majority of customers (98.3\%) didn't bring their own shaving equipments at barber's shop.

Table (4): Shows that the studied barbers who aged $30-<35$, with work experience from $(10-<20)$ years and living in urban area $(18.2 \%, 12.8 \%$ and $15 \%$ respectively) were had satisfactory level of knowledge about HCV and HBV. Moreover, there was statistical significant difference between barbers' knowledge regarding $\mathrm{HCV}$ and $\mathrm{HBV}$ and their level of education $(\mathrm{P}=0.000)$.

Table (5): Illustrates that the studied customers who aged $25-<30$ and those who married $(23.4 \%$ and $21.1 \%$ respectively) were had satisfactory level of knowledge about $\mathrm{HCV}$ and $\mathrm{HBV}$ with no statistical significant difference $(\mathrm{P}=0.576$ and 0.458 respectively). Moreover, customers who had secondary/higher education and living in urban area had a satisfactory level of knowledge regarding $\mathrm{HCV}$ and $\mathrm{HBV}$ with statistical significant difference $(\mathrm{P}=$ 0.007 and 0.039 respectively).

Table (6): Shows that the majority (82.9\%) of barbers in the urban locality had positive attitude toward HCV \&HBV.

Table (7): Shows that more than one-third of rural barbers $(34.5 \%)$ and less than one-third of rural customers $(32.8 \%)$ was smoking goza (shesha). While, only $(13.7 \%)$ of urban barbers and only $(8.8 \%)$ of urban customers visited a dentist. On the other hand, less than three-quarters of the rural barbers $(72.4 \%)$ had history of exposure to blood during their work.

\section{Discussion}

$\mathrm{HCV}$ is a global public health challenge that is mainly transmitted through direct exposure to infected blood such as sharing of injections, blood transfusion and accidental percutaneous exposures. These risk factors are common in certain health-care professions. Egypt is confronted with an HCV disease burden of historical proportions that distinguishes this nation from others (Alter, 2007, Razi et al, 2008 and Mohamoud et al., 2012).

Concerning the age groups of the studied barbers and their customers: It was found that around one-third of barbers and more than one-quarter of their customers were aged $25-<30$ years. Despite that barbing profession is an old work; but it is still present in the Egyptian community. It may be related to unemployment and that general population considered it as an easy work to practice to earn money. This finding similar with Wazir et al, 2008 who studied the awareness among barbers about health hazards associated with their profession in Pakistan and referred that half of barbers were in age ranged from (26-35) years.

The results of the current study reveled that there wasn't any statistical significant differences between the age groups of barbers and their customers and their knowledge regarding $\mathrm{HCV}$ and $\mathrm{HBV}$.

Regarding to educational level of the participants It was found that more than half of barbers and about three-fifths of customers had secondary education, while only (3.4\% and $14.9 \%$ respectively) of them had university education. As well as more than onequarter of barbers and less than one-fifth of customers were illiterate. This finding was in line with Amodio et al, 2009 who found that nearly threefifths of hairdressers had secondary education. Wazir et al., 2008 and Chaudhry et al., 2008 found that nearly three-fifths of their studied samples were illiterate. As well as Waheed et al., 2010 recorded that one-quarter of their sample were illiterate and more than two-fifths of Khan et al., 2009 study sample was illiterate also.

The results of the current study pointed out that there was a significant difference between barbers' level of education and their level of knowledge regarding HCV\&HBV. This finding agreed with those of Wazir et al., 2008, who found that there was a significant difference in level of awareness among barbers in respect of their educational status.

According to residence: It was found that two-thirds of barbers were from urban area; it was explained by that fewer number of barbers in the rural areas. It was observed that all of the visited villages were had one or two barbers' shops. This result was similar to Jokhio et al., 2007 and Shalaby et al., 2007 who observed that the vast majority of their studied samples were from urban area. While, this result was in contrast with Belbacha et al, 2007 who found that more than half of barbers were from rural area.

\section{Recommendations}

Importance of research extension in understanding and assessing knowledge and attitude about HCV and HBV and other health related hazards which associated with barbering profession. The need for ongoing training and retraining programs for barbers regarding the methods of prevention of infectious diseases such as HCV\&HBV. 


\section{References}

1. Alter M., (2007): Epidemiology of hepatitis C virus infection. World Journal of Gastroenterology, pp 13: 2436-2441.

2. Al-Thaqafy M., Balkhy H., Memish Z., Makhdom Y., Ibrahim A., Al-Amri A and AlThaqafi A., (2009): Improvement of the low knowledge, attitude and practice of hepatitis B virus infection among Saudi National Guard personnel after educational intervention, BMC research notes, pp 5:597. http://www.biomedcentral.com/1756-

0500/5/597. Accessed at: 30 October 2012.

3. Amodio E., Di Benedetto M., Gennaro L., Maida C., and Romano N., (2009): Knowledge, attitudes and risk of HIV, HBV and $\mathrm{HCV}$ infections in hairdressers of Palermo city (South Italy). The European Journal of Public Healtheurpub.Oxfordjournals.org 20 (4): pp 433437.

4. Averhoff F., (2012): Infectious diseases related to travel, Centers for Disease Control and Prevention (CDC): Travelers' health, Chapter 3, p 78.

http://wwwnc.cdc.gov/travel/yellowbook/2014/c hapter-3-infectious-diseases-related-totravel/hepatitis-b. Accessed at: August 01, 2013.

5. Belbacha I., Cherkaoui I., Akrim M., Dooley K., and El Aouad R., (2007): Seroprevalence of hepatitis $\mathrm{B}$ and $\mathrm{C}$ among barbers and their clients in the Rabat region of Morocco. Eastern Mediterranean Health Journal (EMHJ), Vol. 17, No. 12, pp 911-918.

6. Chaudhry M., Rizvi F., Ashraf M., Afzal M., and Niazi S, (2008): Knowledge and practices of barbers regarding hepatitis $\mathrm{B}$ and hepatitis $\mathrm{C}$ in Bahra Kahu, Islamabad-Pakistan, 35(1): pp $37-$ 40.

7. Eassa S., Eissa M., Sharaf S., Ibrahim M., and Hassanein O, (2007): Prevalence of Hepatitis C Virus Infection and Evaluation of a Health Education Program in El- Ghar Village in Zagazig, Egypt. Journal of Egyptian Public Health Association, Vol. 82, No, 5 \& 6, pp 380404.

8. Hwang E., and Cheung R., (2011): Global epidemiology of Hepatitis B Virus (HBV) infection. The North American Journal of Medicine and Science; 4(1):7-13.

9. Ismail A., Ziada H., Sheashaa H., and Shehab El-Din A., (2009): Decline of viral hepatitis prevalence among asymptomatic Egyptian blood donors: A glimmer of hope. European Federation of Internal Medicine, 20(5):490-493.
10. Jokhio A., Bhatti T., and Memon M., (2007): Knowledge, attitudes and practices of barbers about hepatitis $\mathrm{B}$ and $\mathrm{C}$ transmission in Hyderabad, Pakistan. Eastern Mediterranean Health Journal, Vol. 16 No.10, p 1080.

11. Khan M., Zhaidi A., Mehar A., Ahmed R., Zahoor S, Sarfaraz A., and Safdar M., (2009): Assessment of knowledge and practice of barbers \& beauticians regarding hepatitis B and C. Gomal Journal of Medical Sciences 2012, Vol. 10, No. 1, pp 127-131.

12. Medhat A., Shehata M., Magder L., Mikhail N., Abdel-baki L., Nafeh M., Abdel-Hamid M., Strickland G., and Fix A., (2002): Hepatitis C in A community in Upper Egypt: Risk factors for infection. American Journal of Tropical Medicine and Hygiene, 66(5), p 633.

13. Mohamoud Y., Mumtaz G., Riome S., Miller DeWolfe and Abu-Raddad L., (2012): The epidemiology of hepatitis $\mathrm{C}$ virus in Egypt: A systematic review and data synthesis, BioMedical Center of Infectious Diseases; pp 13: 288.

14. Poll R., (2009): The role of the community nurse in hepatitis $\mathrm{C}$ diagnosis and treatment. British Journal of Community Nursing, Vol. 14, Issue 7, pp 292 - 296. http://www.internurse.com / . Accessed at: September 27, 2013.

15. Razi A., Rehman R., Naz S., Ghafoor F., and Khan M., (2008): Knowledge attitude and practices of university students regarding hepatitis B and C. Journal of Agricultural and Biological Science, Vol. 5, No. 4, pp 38-40.

16. Shalaby S., Kabbash A., El Saleet G., Mansour N., Omar A., and El Nawawy A., (2007): Hepatitis $B$ and $C$ viral infection: Prevalence, Knowledge, Attitude and Practice among barbers and clients in Gharbia governorate, Egypt. Eastern Mediterranean Health Journal. Vol. 16, No.1, pp1-8.

17. Waheed Y., Saeed U., Safi S., Chaudhry W., and Qadri I., (2010): Awareness and risk factors associated with barbers in transmission of hepatitis $\mathrm{B}$ and $\mathrm{C}$ from Pakistani population: Barber's role in viral transmission. Asian Biomedicine, Vol. 4 No. 3, p 435.

18. Wazir M., Mehmood S., Ahmed A., and Jadoon H., (2008): Awareness among barbers about health hazards associated with their profession. Journal of Ayub Medical College Abbottabad; 20(2), p 35.

19. World Health Organization (WHO), (2012): Prevention \& control of viral hepatitis infection: Framework for global action. www.who.int/topics/hepatitis, pp 2:28. 